\title{
GENETIC VARIABILITY STUDIES AND SCREENING, FOR BLAST RESISTANCE IN ELITE GENOTYPES OF RICE (Oryzasativa L.)
}

\section{MANJUNATHA B \& NIRANJANA KUMARA B}

Agricultural and Horticultural Research Station, Ponnampet, University of Agricultural and Horticultural Sciences, Shivamogga, Karnataka

\begin{abstract}
This research was performed at Agricultural and Horticultural Research station, Ponnampet, in the Indian state of Karnataka. 64 rice genotypes were included in this experiment, which were estimated to study heritability, genetic variability and genetic advance for yield in grains and four yield linked characters. During the 2013 kharif main cropping season, this test was performed using $6 \times 6$ simple lattice designs with two duplications (replications). Significant differences $(p<0.05)$ were revealed by the analysis of variance statistically, which shows the genetic variability's existence among the 64 genotypes for all the studied characteristics. For grain yield, substantial differences were noticed, which ranged from 1365.00 to $5675.00 \mathrm{~kg} / \mathrm{ha}$ and this is with the total mean value of $3840.00 \mathrm{~kg} / \mathrm{ha}$. Yield $\mathrm{kg} / \mathrm{ha}$ exhibited higher PCV and GCV values that suggested the possibility of trait improvisation by selection. Maximum heritability was documented for days to $50 \%$ blooming followed by yield $\mathrm{kg} / \mathrm{ha}$, panicles per meter square and height of the plant. High genetic advance as means percentage and high to medium heritability combined with high GCV were presented for panicles per square metre, and height of plant. Maximum genetic advances in means percent was observed by yield kg per hectare, height of plan (cm), panicles per square metre, and days to flowering for fifty per cent. Large-scale screen was conducted for the genotypes of new rice blast resistance in 64 diverse rice accessions generating from the countries that are popular for rice-growing and it was observed that eight genotypes were resistant.
\end{abstract}

KEYWORDS: Variability, Heritability, Genetic Advance \& Blast

Received: Oct 21, 2017; Accepted: Nov 10, 2017; Published: Dec 15, 2017; Paper Id.: IJASRDEC201757

\section{INTRODUCTION}

Rice is a cereal crop that is self-pollinated. It belongs to the family Graminaeae or Poaceae. It comes under the order Cyperales and class Monocotyledon with the chromosome number $2 n=24$, according to Hooker (1979). A total of 25 species are included under the genus "Oryza". According to Brar (2003), out of these 25 recognized species, 23 species are wild species and two of them, Oryzaglaberrima and Oryzasativaare cultivated. This is capable of surviving as a perennial crop but cultivated as an annual crop. It grows in temperate and tropical countries over a range of climatic and soil conditions and it can yield a ratoon crops for about 30 years. In most of the Asian countries, agriculture and rice play an important role in the economic development. In most of the parts of Asia, rice plays a vital role in society, culture and politics, employing more people directly and indirectly more than any other industry. Particularly in the poorer countries in Asia, a healthy rice industry is critical to the employment of the consumer and rice producers. Proper yields should be achieved by the farmers without causing any harm to the environment in order to make happy living by supplying high quality rice to the rice-eating people at affordable price. Supporting this, a strong research on rice sector helps to decrease the cost, improving the production and to take care of the environmental sustainability. Certainly, for livelihood and productivity, rice research has been a 
key.

The major breeding objective is the yield enhancement in the programs of rice breeding and nature knowledge. The size of the variation in genetics ruling the quantitative characters' inheritance like yield and its constituents is necessary for the improvement of genetics, effectively. For any plant breeder, an acute analysis of the genetic variability parameters like Phenotypic Coefficient of Variability (PCV), Genotypic Coefficient of Variability (GCV), heritability and genetic advance of various characteristics of economic significance is a major requirement to work with the programs of crop improvement. The current examination was commenced in this perspective to clarify information on heritability, variability, genetic advance in capable rice genotypes. An in-depth understanding of genetic resources might also serve in detecting desirable genotypes for forthcoming hybridization program.

Global food security and crop production are challenged by the crop plant diseases produced by multiple pathogens such as bacteria, viruses, fungi and oomycetes. The negative effect of biotic stresses is further increased by the global climate change. Increased temperatures and irregular weather design are expected to change the distribution of geographical pathogen. According to Garrett et al. (2006) and Miluset al. (2009), the effectiveness of prevailing resistance genes is decreased in the varieties of crops by supporting more aggressive pathogen races.

One of the hot spot for rice blast diseases is Ponnampet in the Indian state of Karnataka. Therefore, this test on blast screening amidst 64 rice genotypes was conducted there.

\section{MATERIAL AND METHODS}

The research was performed during kharif, 2013 at Agricultural and Horticultural Research Station, Ponnampet. The required material contained 64 elite rice genotypes (as shown in table 1) seeded in a simple lattice design with two replications at the spacing of $20 \times 15 \mathrm{~cm}$. The observed data were noted on five randomly nominated plants in each entry, in each duplication (replications) for the characters days to 50\% flowering, height of the plant (cm), number of panicles per square metre, excluding harvest which documented in $\mathrm{kg} / \mathrm{plot}$ transformed into $\mathrm{kg} / \mathrm{ha}$. To estimate the phenotypic coefficient of variation (\%), Genetic coefficient of variation (\%), Heritability (\%) (Broad sense), Genetic Advance and Genetic Advance as percent of mean, the data was subjected to INDOSTAT software. As per the classifications proposed by Siva Subramanian and Madhava Menon, the evaluations for variability treated as heritability and genetic advance as percent of mean estimates according to principles suggested by Johnson et al. Blast scoring is also done along with the yield parameters by using the standard blast scale 0-9 (see Table 2).

\section{RESULTS AND DISCUSSIONS}

In the current study, the existence of important variations among genotypes for all characteristics is revealed by the analysis of variance. Table 2 shows variability estimates $i$. e., Genetic coefficient of variation (\%), the mean Heritability (\%) (Broad sense), Phenotypic coefficient of variation (\%) and Genetic Advance as a percent of mean. All characteristics under study have increased phenotypic coefficient of variation than the genotypic coefficient of variation. According to Roy et al. (2001), the intensity of genotypic coefficient of variation and phenotypic coefficient of variation was moderate to high for the traits panicles per square metre and yield. Roy (2001) says that for yield per hectare, the high PCV was observed. The possibility of improvement through selection is indicated by the high GCV obtained for number of panicles per square metre. The extent of genetic variability percent for a trait is measured by the genotypic coefficient of variation, but does not calculate the extent of genetic variation which is inherited. For all the characters, 
heritability estimates were high. The heritability evaluations along with advancement in genetics can be beneficial to guess the result of selection in selection programmes. According to Thirualaraoet al. 2014, the characters like yield, days to fifty percent flowering and height of plant exhibited high intensity of genetic advance as percent of mean. The characters like height of plant, panicles per square metre, days to fifty percent flowering and yield have high heritability along with genetic advance as percent of mean specify that these traits attributable to seasoning gene effects which are fixable. This reveals that character improvements would be possible via direct selection.

Tanksley and McCouch, (1997) says that, modern breeding and domestication has decreased genetic diversity of crop plants by interchanging traditional farmer cultivars and land races with high, modern yielding varieties. Even though, this has permitted filtering out genes, that cause detrimental characters, now the decrease in genetic variation restricts the plant breeders' choices to improve new varieties with the prevailing germplasm. To protect the crops against highly unpredictable abiotic and biotic stresses that are met in agricultural systems and to meet the consumer demands, new varieties are constantly needed. Identification of original functional genes or alleles is required, for breeding the improved varieties and these demands for creating actual use of our global crop genetic resources existing in seed bank collections. A wide range of genetic diversity is represented by these seed collections, which is crucial for enhancing and maintaining the potential of the yield and other quality traits, since they can deliver new foundations of tolerance and resistance to numerous stresses. For highly relevant traits, many of the genes in modern crop cultivars have been converted from their landraces and wild relatives. For example, the Rht and sd-1 genes that discuss dwarf stature in rice and wheat, respectively (Hoisington et al., 1999; Hedden, 2003). The primary gene pool for rice cultivars are the six wild species $O$. longistaminata, O. rufipogon, O. breviligulata, O. glumaepatula, O. nivara, and O. meridionalis together with the two cultivated species O. glaberrima and O. sativa. According to Khush (1997), these varieties have been identified as the primary gene pool because, these can be easily transported between these species. For many relevant genes, the wild species have been used as a foundation for rice breeding. The source of broad-spectrum rice blast resistance genes was suggested to be $O$. rufipogon (Ram et al., 2007).

\section{CONCLUSIONS}

64 rice genotypes besides one standard checks were calculated for four yield and yield attributing traits. The results obtained from the current study on heritability, variability, and genetic advance showed a scope for development of grain yield via selection, eight genotypes' were shown as blast resistant.

\section{REFERENCES}

1. Biol. 35, 25-34. doi: 10.1023/A:1005810616885.

2. Brar DS, Khush GS (2003) Utilization of wild species of genus Oryzae in rice improvement. In: J S Nanda, Sharma SD Monograph on Genus Oryzae 283309.

3. Garrett, K. A., Dendy, S. P., Frank, E. E., Rouse, M. N., and Travers, S. E. (2006). Climate change effects on plant disease: genomes to ecosystems. Annu. Rev. Phytopathol. 44, 489-509. doi: 10.1146/annurev. phyto.44.070505.143420.

4. S. K. Savita et al., Genetic Variability of Water Use Efficient RIL (S) of the Cross GKVK 4 X NRCG 12473 and Identification of Elite Genotypes in Groundnut (Arachis Hypogaea L.), International Journal of Agricultural Science and Research (IJASR), Volume 6, Issue 5, September - October 2016, pp. 375-380

5. Ghazanfar, M. U., A. Habib and S. T. Sahi, 2009. Screening of rice germplasm against Pyriculariaoryzae the cause of rice 
blast disease. Pak. J. Phytopathol., 21: 41-44.

6. Hedden, P. (2003). The genes of the green revolution. Trends Genet. 19, 5-9. doi: 10.1016/S0168-9525(02)00009-4.

7. Hoisington, D., Khairallah, M., Reeves, T., Ribaut, J. M., Skovmand, B., Taba, S., et al. (1999). Plant genetic resources: what can they contribute toward increased crop productivity? Proc. Natl. Acad. Sci. U. S. A. 96, 5937-5943. doi:10.1073/pnas. 96.11 .5937

8. Hooker JD (1979) the Flora of British India. Vol 2 L Reeve Co Kent, England 25.

9. L. Madhavilatha \& M. Subba Rao, Performance of Elite Finger Millet Cultures for Grain Yield, Yield Influencing Traits and Blast Tolerance, International Journal of Agricultural Science and Research (IJASR), Volume 5, Issue 1, January - February 2015, pp. 111-114

10. Johnson, H. W. Robinson, H. F. and Costock, R. E., Estimates of genetic and environmental variability in Soyabean. Agronomy Journal, 47(7): 314-318 (1955).

11. Khush, G. S. (1997). Origin, dispersal, cultivation and variation of rice. Plant Mol.

12. Milus, E. A., Kristensen, K., and Hovmoller, M. S. (2009). Evidence for increased aggressiveness in a recent widespread strain of Pucciniastriiformis f. sptriticicausing stripe rust of wheat. Phytopathology 99, 89-94. doi: 10.1094/PHYTO99-1-0089.

13. Ram, T., Majumder, N. D., Mishra, B., Ansari, M. M., and Padmavathi, G. (2007). Intro gression of broad-spectrum blast resistance gene(s) into cultivated rice (Oryzasativasspindica) from wild rice O. rufipogon. Curr. Sci. 92, 225-230.

14. Roy, B. Hossain, M. and Hossain, F., Genetic variability in yield components of rice (OryzasativaL.). Environment and Ecology. 19(1): 186-189 (2001).

15. Singh S. K., Bhati P. K., Sharma A, Sahu V (2015) Super hybrid rice in China and India: current status and future prospects. Int J Agric and Biol 17: 221-232.1. Genetic variability and association analysis in rice. International Journal of Applied Biology and Pharmaceutical Technology. 5(2): 63-65.

16. Siva Subramanian, S. and Madhavamenon, P., Combining ability in rice. Madras Agricultural Journal. 60: 419-421 (1973)

17. Tanksley, S. D., and McCouch, S. R. (1997). Seed banks and molecular maps: unlocking genetic potential from the wild. Science 277, 1063-1066. doi:10.1126/science.277.5329.1063.

18. Thirumala Rao, V. Chandra Mohan, Y. Bhadru, D. Bharathi, D. and Venkanna,. V. (2014)

19. Vaithiyalingan, M. and Nadarajan, N., Genetic variability, heritability and genetic advance in $F_{1}$ population of inter subspecific crosses of rice. Crop Research. 31(3): 476-477 (2006).

20. Venkanna, V., Lingaiah, N., Raju, Ch and Rao, V. T., Genetic studies for quality traits of F population of rice (Oryzasativa L.). International Journal of Applied Biology and Pharmaceutical Technology.5 (2): 125-127 (2014).

Table 1: Rice Genotypes, Grain Type and Blast Disease Reaction During the Experiment in Research Station

\begin{tabular}{|c|c|c|c|c|c|}
\hline Genotypes & Blast Score & Grain Type & Genotypes & Blast Score & Grain Type \\
\hline IET 23241 & 3 & MS & IET 23632 & 3 & SB \\
\hline IET 23259 & 1 & MS & IET 23633 & 3 & MS \\
\hline IET 23606 & 3 & MS & IET 23634 & 5 & SB \\
\hline IET 23607 & 7 & MS & IET 23635 & 3 & MS \\
\hline IET 23608 & 3 & MS & IET 23636 & 3 & MB \\
\hline IET 23609 & 3 & MS & IET 23637 & LS \\
\hline CPHR 32 & 3 & MS & IET 23638 & MS \\
\hline IET 23610 & 3 & MS & IET 23639 & 5 & MS \\
\hline
\end{tabular}




\begin{tabular}{|c|c|c|c|c|c|}
\hline \multicolumn{6}{|c|}{ Table 1: Contd., } \\
\hline IET 23611 & 3 & MS & IET 23640 & 7 & LB \\
\hline IET 23612 & 5 & LS & IET 23641 & 3 & MS \\
\hline IET 23613 & 7 & MB & IET 23642 & 5 & MB \\
\hline IET 23614 & 5 & SB & IET 23643 & 3 & LB \\
\hline Swarna & 7 & SB & IET 23644 & 1 & LS \\
\hline IET 23615 & 5 & LS & IET 23645 & 3 & MS \\
\hline IET 23616 & 3 & SB & IET 23646 & 5 & SB \\
\hline IET 23617 & 1 & MS & IET 23647 & 1 & MS \\
\hline IET 23618 & 1 & MS & IET 23648 & 9 & LS \\
\hline IET 23619 & 3 & MS & IET 23649 & 3 & LS \\
\hline IET 23620 & 3 & MS & IET 23650 & 5 & $\mathrm{MS}$ \\
\hline IET 23621 & 3 & $\mathrm{LS}$ & IET 23651 & 5 & MS \\
\hline IET 23622 & 3 & LS & IET 23652 & 3 & SB \\
\hline Samba mahsuri & 3 & SB & IET 23653 & 3 & SB \\
\hline IET 23623 & 1 & MS & IET 23654 & 3 & MS \\
\hline IET 23624 & 3 & MS & IET 23655 & 5 & $\mathrm{MS}$ \\
\hline IET 23625 & 5 & MS & IET 23656 & 3 & LS \\
\hline IET 23626 & 3 & MB & IET 23657 & 5 & MS \\
\hline IET 23627 & 3 & SB & IET 23658 & 5 & $\mathrm{LS}$ \\
\hline Thunga & 3 & LB & IET 23659 & 3 & $\mathrm{MS}$ \\
\hline IET 23628 & 5 & MS & IET 23660 & 1 & MS \\
\hline IET 23629 & 3 & MB & IET 23661 & 3 & MS \\
\hline IET 23630 & 1 & $\mathrm{MB}$ & IET 23662 & 3 & SB \\
\hline IET 23631 & 3 & LS & IET 23663 & 7 & LS \\
\hline
\end{tabular}

Table 2: Standard Screening Scale (0-9 Grade for Disease Rating) was Used for Blast Disease of Indica Rice (Source-Irri, 1996; Ghazanfaret Al., 2009)

\begin{tabular}{|c|c|c|}
\hline Grade & Disease Severity & Host Response \\
\hline 0 & Lesion are not present & Highly resistant (HR) \\
\hline 1 & Small brown specks of pin point size on lower leaves & Resistant (R) \\
\hline 2 & $\begin{array}{l}\text { Small roundish to slightly elongated, necrotic gray spots, about } \\
1-2 \mathrm{~mm} \text { in diameter, with distinct brown margin. Lesions are } \\
\text { mostly found on the lower leaves }\end{array}$ & $\begin{array}{l}\text { Moderately resistant } \\
(\mathrm{MR})\end{array}$ \\
\hline 3 & $\begin{array}{l}\text { Lesion type same as in 2,but significant number of lesions on the } \\
\text { upper leaves }\end{array}$ & $\begin{array}{l}\text { Moderately resistant } \\
(\mathrm{MR})\end{array}$ \\
\hline 4 & $\begin{array}{l}\text { Typical susceptible blast lesions, } 3 \mathrm{~mm} \text { or longer infecting less } \\
\text { than } 4 \% \text { ofleaf area }\end{array}$ & $\begin{array}{l}\text { Moderately susceptible } \\
\text { (MS) }\end{array}$ \\
\hline 5 & $\begin{array}{l}\text { Typical susceptible blast lesions of } 3 \mathrm{~mm} \text { or longer infecting } 4 \text { - } \\
10 \% \text { ofthe leaf area }\end{array}$ & $\begin{array}{l}\text { Moderately susceptible } \\
\text { (MS) }\end{array}$ \\
\hline 6 & $\begin{array}{l}\text { Typical susceptible blast lesions of } 3 \mathrm{~mm} \text { or longer infecting } 11- \\
25 \% \text { ofthe leaf area }\end{array}$ & Susceptible (S) \\
\hline 7 & $\begin{array}{l}\text { Typical susceptible blast lesions of } 3 \mathrm{~mm} \text { or longer infecting } 26- \\
50 \% \text { ofthe leaf area }\end{array}$ & Susceptible (S) \\
\hline 8 & $\begin{array}{l}\text { Typical susceptible blast lesions of } 3 \mathrm{~mm} \text { or longer infecting } 51- \\
75 \% \text { ofthe leaf area many leaves are dead }\end{array}$ & Highly susceptible (HS) \\
\hline 9 & $\begin{array}{l}\text { Typical susceptible blast lesions of } 3 \mathrm{~mm} \text { or longer infecting more } \\
\text { than } 75 \% \text { leaf area affected }\end{array}$ & Highly Susceptible(HS) \\
\hline
\end{tabular}

Table 3: Various Genetic Variability Parameters

\begin{tabular}{|c|c|c|c|c|}
\hline $\begin{array}{l}\text { Traits } \\
\text { Parameters }\end{array}$ & $\begin{array}{c}\text { Days To Fifty } \\
\text { Percent Flowering }\end{array}$ & $\begin{array}{l}\text { Plant Height } \\
(\mathrm{Cm})\end{array}$ & $\begin{array}{l}\text { Panicles } \\
\text { Per } \mathbf{M}^{2}\end{array}$ & $\begin{array}{c}\text { Yield } \\
(\mathrm{Kg} / \mathrm{Ha})\end{array}$ \\
\hline Mean & 120.80 & 70.22 & 315.50 & 3840.12 \\
\hline Range & 98-139 & $48-102$ & $200-641$ & $1365-5675$ \\
\hline $\begin{array}{l}\text { Genotypic } \\
\text { variability }\end{array}$ & 70.42 & 137 & 6399.03 & 1057127 \\
\hline $\begin{array}{l}\text { Phenotypic } \\
\text { variability }\end{array}$ & 71.4 & 142.4 & 7230.6 & 1081241 \\
\hline GCV & 6.94 & 16.66 & 25.36 & 26.77 \\
\hline PCV & 6.99 & 16.99 & 26.95 & 27.07 \\
\hline
\end{tabular}




\begin{tabular}{|l|c|c|c|c|}
\hline \multicolumn{5}{|c|}{ Table 3: Contd., } \\
\hline Heritability & 0.98 & 0.96 & 0.88 & 0.97 \\
\hline Genetic advance & 17.16 & 23.64 & 155.02 & 2094.27 \\
\hline $\begin{array}{l}\text { Genetic advance } \\
\text { as percent mean }\end{array}$ & 14.12 & 33.67 & 49.14 & 54.54 \\
\hline
\end{tabular}

